\title{
Analisis Saham Syariah Efisien dengan Pendekatan Shari'a Compliant Asset Pricing Model (SCAPM) pada Jakarta Islamic Index (JII)
}

\author{
Zainul Hasan Quthbi \\ UIN Sunan Kalijaga Yogyakarta \\ email: zainul.hasan.quthbi@gmail.com
}

\begin{abstract}
The objective of this article is to analyze the Islamic stocks are relatively efficient for investment decisions using SCAPM (Shari'a Compliant Asset Pricing Model). SCAPM is a modified form of the CAPM (Capital Asset Pricing Model) which aims to frame the analysis model within the framework of Shari'a. The data collection technique is documentation of data that is secondary. 13 samples used in the study of Islamic stocks with consistent criteria of Islamic stocks enter the JII (Jakarta Islamic Index) study period in December 2013 to November 2016 and has a positive individual stock returns. Results from the study showed there were 9 of Islamic stocks are relatively efficient and the 4 remaining inefficient. Shares of PT. Adaro Energy has the largest RVAR value means having the most excellent stock performance.
\end{abstract}

Keywords: stock; shari'a; efficient; SCAPM.

\begin{abstract}
Abstrak: Artikel ini bermaksud untuk menganalisis saham syariah yang tergolong efisien untuk keputusan investasi dengan menggunakan SCAPM (Shari'a Compliant Asset Pricing Model). SCAPM adalah bentuk modifikasi dari CAPM (Capital Asset Pricing Model) yang bertujuan agar kerangka model analisis masih dalam kerangka syariah. Teknik pengumpulan data adalah dokumentasi dari data yang bersifat sekunder. Digunakan 13 sampel saham syariah pada penelitian ini dengan kriteria saham syariah yang konsisten masuk pada JII (Jakarta Islamic Index) periode penelitian Desember 2013 hingga November 2016 dan memiliki pengembalian saham individual positif. Hasil dari penelitian menunjukkan terdapat 9 saham syariah yang tergolong efisien dan 4 sisanya tidak efisien. Saham PT. Adaro Energy memiliki nilai RVAR terbesar yang berarti memiliki kinerja saham paling baik.
\end{abstract}

Kata Kunci: saham; syariah; efisien; SCAPM. 


\section{Pendahuluan}

Kegiatan investasi merupakan suatu kegiatan yang tidak bisa dilepaskan dalam pembangunan perekonomian suatu negara. Apabila terjadi kelesuan dalam sisi investasi maka kelesuan perekonomian juga akan terjadi, sehingga penting bagi negara untuk meningkatkan volume investasi. Sekarang ini, dengan hadirnya pasar modal tentu akan memudahkan siapa pun yang ingin berinvestasi. Hebatnya lagi investor muslim saat ini sudah bisa berinvestasi secara syariah di pasar modal, bahkan saham syariah menjadi primadona investasi saat ini.

Di Indonesia sendiri menurut Badan Pusat Statistik (BPS), persentase penduduk muslim Indonesia sekitas 87 persen. Artinya dengan mayoritas penduduk muslim, isu kepatuhan syariah penting untuk diangkat yang memiliki nilai-nilai dasar Islami. Nilai dasar ini perlu untuk ditawarkan kepada masyarakat sebagai nilai jual dalam investasi. Bahkan bukan hanya negara mayoritas muslim saja yang mengembangkan investasi syariah, tetapi negara-negara barat seperti Inggris dan Amerika Serikat sudah lama mengenalkan saham syariah. Hal ini dikarenakan pasar dari saham syariah cukup besar karena investor non-muslim juga tertarik melakukan investasi pada saham syariah. Kualitas laba yang baik menjadi salah satu alasan investror tertarik dengan saham syariah. Penelitian yang dilakukan Ismail et. al. (Ismail 2015) menunjukkan bahwa di Malaysia kualitas laba perusahaan syariah lebih tinggi dibanding perusahaan lainnya. Hal ini bisa berdampak datangnya investor asing untuk berinvestasi pada saham syariah.

Dalam investasi tentu tidak bisa kita lepaskan dari risiko dan return. Dua hal tersebut selalu menjadi alasan investor dalam memilih emiten untuk berinvestasi. Secara teoritis risiko dan return memiliki hubungan yang positif. Dalam dunia keuangan konvensional konsep risiko dan return pertama kali dipopulerkan oleh Markowitz (1955) dengan memperkenalkan model yang disebut sebagai two-parameter model yang menjelaskna bahwa investor harus fokus pada dua parameter yaitu return yang diharapkan dari 
suatu aset dan risiko yang dilihat dari standar deviasi return aset tersebut (Muhammad, Manajemen Keuangan Syari'ah 2014). Model yang dipopulerkan Markowitz tersebut kemudian dikembangkan oleh William Sharpe, Lintnet dan Mossin (1960) yang memperkenalkan CAPM (Capital Asset Pricing Model). CAPM menjelaskan hubungan antara return dan risiko sistematis ( $\beta$ ). Menurut Jogiyanto (Hartono, Teori Portopolio dan Analisis Investasi 2013) beta yang dihitung menurut data historis dapat digunakan untuk mengestimasi beta di masa yang akan datang.

Namun CAPM tidak terlepas dari kelemahan. CAPM telah dikritik dalam banyak penelitian mengenai pinjaman bebas risiko, investor memaksimalkan investasi satu periode dan fokus hanya pada risiko dan pengembalian satu-periode portopolio (Elbannan 2015). Terlebih lagi dalam CAPM terdapat risk free return $\left(\mathrm{R}_{\mathrm{f}}\right)$ yang bertentangan dengan investasi Islam. Dalam investasi Islam tidak diperbolehkan return yang bebas risiko. Terlebih lagi $R_{f}$ merepresentasikan nilai waktu uang yang sama dengan riba, sehingga perlu dilakukan modifikasi dalam model CAPM. Di era teknologi sekarang ini sudah banyak pihak memodifikasi CAPM yang didasari oleh alasan yang kuat (Hadi 2011). Salah satu modifikasi yang bisa dilakukan adalah dengan pembentukan model CAPM sesuai prinsip syariah karena sebagai investor muslim tentu kepatuhan syariah sangat diutamakan. Hanif (Hanif 2011) mencoba merumuskan hubungan risiko dan return dalam model syariah. Menurutnya terdapat kebutuhan untuk menganalisis model harga sekuritas yang didasarkan pada nilai-nilai kepatuhan syariah, mencocokkan dengan sistem keuangan syariah dan membentuk alternatif yang diperlukan.

Pada penelitian-penelitian sebelumnya, untuk menganalisis saham yang efisien digunakan model CAPM. Dalam penelitian ini akan digunakan model SCAPM (Shari'a Compliant Asset Pricing Model) yang merupakan modifikasi model CAPM. Tujuan digunakan model SCAPM ini untuk menganalisis saham syariah yang didasarkan kepada kepatuhan syariah. Saat ini investor muslim 
yang rasional bukan hanya didasarkan return yang tinggi tetepi juga harus didasarkan pada kepatuhan syariah.

\section{Landasan Teori}

\section{Risiko Investasi}

Menurut Halim (Halim 2005), risiko dalam konteks manajemen investasi merupakan besarnya penyimpangan antara tingkat pengembalian yang diharapkan (expected return) dengan tingkat pengembalian antual (actual return). Hampir setiap investasi di dunia ini mengandung risiko. Menurut Husnan (Husnan 2009) yang bisa dilakukan investor adalah memperkirakan jumlah keuntungan yang diharapkan dari investasi, dan seberapa jauh kemungkinan hasil yang sebenarnya nanti akan menyimpang dari hasil yang diharapkan.

Risiko dalam Islam diakui bahkan harus ada dalam setiap investasi. Islam tidak mengakui investasi bebas risiko karena akan ada tambahan yang bisa mengandung unsur ribawi. Konsep risiko dan ketidakpastian juga sering dibandingkan dengan konsep gharar dalam hukum Islam. Konsep gharar (ketidakpastian) memiliki interpretasi ketidaktepatan dan ketidakcukupan informasi yang tersedia pada pihak yang melakukan kontrak (Muhammad, Manajemen Keuangan Syari'ah 2014). Ketidakcukupan informasi tersebut dapat berpotensi menjadi konflik antara pihak-pihak yang bertransaksi.

\section{CAPM (Capital Asset Pricing Model)}

Investor penting untuk bisa mengestimasi return. Maka untuk mengestimasi diperlukan suatu model. Salah satu model yang dianggap cukup akurat adalah CAPM. Tujuan dari CAPM adalah untuk menentukan tingkat pengembalian yang diisyaratkan (required rate of return - RRR) minimum dari investasi yang berisiko (Halim 2005). CAPM digunakan untuk menentukan harga aset ketika terjadi ekuilibrium, dalam keadaan tersebut suatu saham akan dipengaruhi risiko. Untuk pengukuran risiko model CAPM 
menggunakan beta. Investasi yang efisien adalah investasi yang memberikan risiko tertentu dengan tingkat keuntungan terbesar, atau tingkat keuntungan tertentu dengan risiko kecil (Husnan 2009).

Sharpe dan Lintner menyatakan bahwa harga sekuritas hanya ditentukan oleh keterkaitan return saham dengan return pasar yang terdiri dari semua sekuritas berisiko. Bentuk standar yang kemudian dikembangkan oleh Sharpe, Lintner dan Mossin adalah sebagai berikut (Hartono, Menguji Pasar Modal Akibat Suatu Peristiwa 2010):

$$
\mathrm{E}\left(\mathrm{R}_{\mathrm{i} . \mathrm{t}}\right)=\mathrm{R}_{\mathrm{BR} . \mathrm{t}}+\beta_{\mathrm{i} . \mathrm{t}}\left[\mathrm{E}\left(\mathrm{R}_{\mathrm{M} . \mathrm{t}}\right)-\mathrm{R}_{\mathrm{BR} . \mathrm{t}}\right]
$$

Dimana:

$\mathrm{E}\left(\mathrm{R}_{\mathrm{i}, \mathrm{t}}\right) \quad$ : Tingkat ekspektasi keuntungan yang layak untuk sekuritas ke-i pada periode ke-t

$\mathrm{R}_{\mathrm{BR} . \mathrm{t}} \quad$ : Tingkat keuntungan investasi bebas risiko ke-t

$\mathrm{B}_{\mathrm{i} . \mathrm{t}} \quad$ : Beta sekuritas ke-i pada periode ke-t

$\mathrm{R}_{\mathrm{M} . \mathrm{t}} \quad$ : Tingkat keuntungan portopolio pasar periode ke-t

\section{SCAPM (Shari'a Compliant Asset Pricing Model)}

SCAPM merupakan betuk modifikasi dari CAPM yang ditujukan untuk mengukur risiko dan return dalam kerangka syariah. Seperti diketahui CAPM lahir dari lingkungan bunga yang tidak sesuai dengan ajaran syariat Islam. Dalam CAPM terdapat komponen bebas risiko $\left(\mathrm{R}_{\mathrm{f}}\right)$ yang bertentangan dengan prinsip syariah. Hanif (Hanif 2011) menjelaskan bahwa komponen $R_{f}$ terdiri dari dua hal, yaitu (1) riil $\mathrm{R}_{\mathrm{f}}$ dan (2) biaya infasi. Riil $\mathrm{R}_{\mathrm{f}}$ mewakili nilai waktu uang yang berarti menjadikan uang sebagai komoditas sehingga dilarang dalam syariat karena merupakan implikasi dari bunga. Di Indonesia sendiri untuk $\mathrm{R}_{\mathrm{f}}$ digunakan SBI (Sertifikat Bank Indonesia). Komponen $\mathrm{R}_{\mathrm{f}}$ kedua adalah inflasi, karena inflasi belum ada pelarangannya dalam kerangka syariah maka Hanif (Hanif 2011) membentuk persamaan : 
Zainul Hasan Quthbi

$$
R_{j}=N+\left(R_{m}-N\right) \beta
$$

Dimana $\mathrm{R}_{\mathrm{j}}$ merupakan return sekuritas, $\mathrm{N}$ adalah biaya inflasi, $\mathrm{R}_{\mathrm{m}}$ ratarata pengembalian portofolio pasar dan $\beta$ adalah beta sekuritas pasar.

Namun menurut Cohen et. al., (Randolf B. Cohen n.d.) bahwa CAPM diduga gagal ketika menggunakan inflasi. Garis pasar sekuritas CAPM ( SML) yang menggambarkan hubungan return rata-rata aset dan beta CAPM lebih curam dari yang diperkirakan ketika inflasi rendah atau negatif. Sebaliknya jika inflasi tinggi, SML akan dangkal dari apa yang diprediksikan oleh Sharpe dan Lintner. Hal ini berarti model dianggap gagal dalam mengontrol kompensasi risiko yang diperlukan investor secara tepat.

Dalam asumsi dasar CAPM adalah tidak terjadi inflasi dan ketika inflasi dimasukkan dalam model maka model tersebut diduga gagal. Oleh karena itu dalam penelitian ini komponen yang dimasukkan untuk menggantikan $\mathrm{R}_{\mathrm{f}}$ adalah imbalan SBIS (Sertifikat Bank Indonesia Syariah). SBIS sendiri adalah instrumen khusus bank syariah yang menggunakan akad ju'alah sehingga sesuai dengan kerangka syariah. Artinya SBIS bisa dikatakan model syariah dalam menggantikan suku bunga acuan yang dikeluarkan bank Indonesia yang biasanya digunakan sebagai $\mathrm{R}_{\mathrm{f}}$. Adapun kemudian model yang digunakan dalam penelitian ini adalah;

$$
\mathrm{RRR}=\mathrm{SBIS}+\left(\mathrm{R}_{\mathrm{m}}-\mathrm{SBIS}\right) \beta_{\mathrm{i}}
$$

Dimana :

RRR : Tingkat Pengembalian yang Diisyaratkan

SBIS : : Sertifikat Bank Indonesia Syariah

$\mathrm{R}_{\mathrm{m}} \quad$ : Return Pasar

$\beta_{\mathrm{i}} \quad$ : Risiko Sistematis 
Analisis Saham Syariah Efisien dengan Pendekatan...

\section{Saham Efisien}

Saham efisien adalah kelompok saham yang berada dalam kelompok yang layak ditawarkan ke para investor ekspektasi return maksimum atas berbagai level risiko dan juga risiko minimum untuk berbagai level ekspektasi return (William F. Sharpe 1995). Menurut Jogiyanto Hartono (Hartono, Teori Portopolio dan Analisis Investasi 2013) saham efisien merupakan saham-saham dengan tingkat pengembalian individu lebih besar dari pengembalian yang diharapkan

\section{RVAR (Reward to Variabelity Ratio)}

William Sharpe memperkenalkan RVAR (Reward to Variabelity Ratio) untuk mengukur kinerja suatu portofolio saham. Pengembalian yang rendah belum tentu memiliki kinerja yang buruk sehingga pengembalian yang rendah harus disesuaikan dengan risikonya. Adapun persamaan untuk mengukur RVAR adalah sebagai berikut:

$$
\mathrm{RVAR}=\frac{\text { Excess return }}{\text { Satndard Deviation }}
$$

Dimana excess return didapatkan dari $\mathrm{R}_{\mathrm{i}}-\mathrm{R}_{\mathrm{f}}$. Karena pada penelitian ini menggunakan pendekatan SCAPM yang tidak mengakui risk free $\left(\mathrm{R}_{\mathrm{f}}\right)$ maka SBIS tetap digunakan dalam mengganti $\mathrm{R}_{\mathrm{f}}$.

\section{Metode Penelitian}

Penelitian ini bersifat deskriptif yang merupakan penelitian terhadap masalah-masalah berupa fakta-fakta saat ini dari suatu populasi (Supomo 2014). Pendekatan kuantitaif digunakan dalam penelitian ini karena menggunakan angka-angka dalam teknik analisis. Data yang digunakan dalam penelitian ini adalah data sekunder dengan teknik pengumpulan dokumentasi. Populasi dalam penelitian ini adalah saham-saham syariah yang terdaftar pada JII (Jakarta Islamic Index). Kemudian disaring lagi untuk pengambilan sampel. Kriteria sampel yang digunakan adalah saham-saham syariah yang konsisten terdaftar pada JII dari Desember 2013 hingga 
November 2016. Selain itu juga diambil saham-saham syariah yang memiliki rata-rata tingkat pengembalian bulanan positif, karena perusahaan dengan tingkat pengembalian negatif tidak termasuk saham yang efisien dan investor tentu tidak akan mengharapkan return yang negatif dalam suatu investasi.

Adapun tahap-tahap dalam penelitian ini adalah sebagai berikut:

1. Menghitung tingkat pengembalian saham individu dengan persamaan yang digunakan

$$
\mathrm{R}_{\mathrm{i}}=\frac{\left(\mathrm{P}_{\mathrm{t}}-\mathrm{P}_{\mathrm{t}-1}\right)+\mathrm{D}}{\mathrm{P}_{\mathrm{t}-1}}
$$

2. Menghitung tingkat pengembalian pasar dengan persamaan $R_{m}=$ $\frac{\left(\mathrm{IHSGt}-\mathrm{IHSG}_{\mathrm{t}-1}\right)}{\mathrm{IHSG}_{\mathrm{t}-1}}$

3. Menghitung rata-rata imbalan SBIS secara bulanan yang dimasukkan dalam model untuk mengganti $\mathrm{R}_{\mathrm{f}}$.

4. Menghitung tingkat risiko sistematis masing-masing saham $(\beta)$ dengan persamaan

$$
\beta=\frac{\sigma \mathrm{iM}}{\sigma^{2} \mathrm{M}}
$$

5. Menghitung required rate of return menggunakan persamaan SCAPM.

6. Mengelompokkan saham-saham effisin.

7. Memeringkatkan saham menggunakan RVAR.

\section{Hasil dan Pembahasan}

\section{Tingkat Pengembalian Saham Individu $\left(\mathbf{R}_{\mathbf{i}}\right)$}

Dari 19 saham syariah yang konsisten terdaftar pada JII (Jakarta Islamic Index) dari periode Desember 2013 hingga November 2016, terdapat 13 saham syariah yang memiliki rata-rata tingkat pengembalian saham individu positif. Saham PT Telkom (TLKM) memiliki rata-rata tingkat pengembalian tertinggi sebesar 0,0164 atau $1,64 \%$. Sementara saham dengan tingkat 
pengembalian positif terendah adalah saham PT Bumi Serpong Damai (BSDE) sebesar 0,0036 atau 0,36\%.

Tabel 1. Rata-Rata Tingkat Pengembalian Saham Individu

Periode Desember 2013 - November 2016

\begin{tabular}{lll}
\hline No. & Kode Saham & $\mathbf{R}_{\mathbf{i}}$ \\
\hline 1 & ADRO & 0,034601 \\
2 & AKRA & 0,010768 \\
3 & ASII & 0,006087 \\
4 & BSDE & 0,00363 \\
5 & ICBP & 0,016131 \\
6 & INDF & 0,008047 \\
7 & KLBF & 0,008091 \\
8 & LSIP & 0,005462 \\
9 & SMRA & 0,012948 \\
10 & TLKM & 0,016432 \\
11 & UNTR & 0,004862 \\
12 & UNVR & 0,01249 \\
13 & WIKA & 0,010812 \\
\hline
\end{tabular}

\section{Tingkat Pengembalian Pasar $\left(\mathbf{R}_{\mathbf{m}}\right)$}

Selama periode Desember 2013 hingga November 2016 tingkat pengembalian pasar tertinggi terjadi pada Oktober 2015 sebesar 0,0547 atau 5,47\%. Berarti Oktober 2015 aktivitas perdagangan pada pasar saham cukup aktif. Sementara tingkat pengembalian pasar terkecil terjadi pada April 2015 sebesar $-0,0783$ atau $7,83 \%$ yang berarti terjadi kelesuan aktivitas pasar saham pada periode ini. Sementara rata-rata dari tingkat pengembalian pasar dari Desember 2013 hingga November 2016 sebesar 0,005915 atau 0,5915 \%. Performance investasi dikatakan baik ketika tingkat pengembalian pasar lebih dari tingkat pengembalian bebas risiko. Karena pada penelitian ini kita tidak memasukkan unsur bebas risiko dan menggantinya dengan 
Zainul Hasan Quthbi

SBIS yang menggunakan akad ju'alah, sehingga bisa disimpulkan performance investasi saham bisa dikatakan baik ( $\left.\mathrm{R}_{\mathrm{m}}>\mathrm{SBIS}\right)$.

\section{Tingkat Imbalan SBIS}

Merujuk kepada data yang diterbitkan Bank Indonesia bahwa imbalan SBIS tertinggi pada periode penelitian ini terjadi pada Januari 2014 sebesar 0,0723 atau 7,23\%. Sementara imbalan SBIS terendah terjadi pada bulan Oktober dan November 2016, sebesar 0,059 atau 5,9\%. SBIS digunakan untuk menggantikan SBI yang biasa digunakan sebagai $\mathrm{R}_{\mathrm{f}}$ dalam komponen CAPM. Rata-rata imbalan SBIS selama Desember 2013 hingga November 2016 adalah 0,0677661 atau 6,77661\% per tahun. Sehingga rata-rata pertahun dibagi 12 bulan akan ditemukan rata-rata per bulan sebesar 0,005647 atau $0,5647 \%$.

\section{Tingkat Risiko Sitematis $\left(\boldsymbol{\beta}_{\mathrm{i}}\right)$ Masing-masing Saham Individu}

Dari hasil analisis data, rata-rata beta saham individu dari sampel yang digunakan sebesar 1,206908. Artinya rata-rata saham syariah yang digunakan sebagai sampel pada penelitian ini tergolong saham agresif $(\beta>1)$ karena saham cenderung naik dan turun lebih tinggi daripada pasar. Sementara saham paling agresif adalah saham PT. Summarecon Agung dengan beta sebesar 2,207159. Adapun saham yang tergolong paling defensif $(\beta<1)$ adalah saham PT. AKR Corporindo dengan beta sebesar 0,337429. Saham defensif berarti saham yang naik turunnya cenderung lebih rendah daripada indeks pasar secara umum (general market index). Berikut adalah hasil perhitungan beta masing-masing saham individu.

Tabel 2. Tingkat Risiko Sistematis $\left(\beta_{\mathrm{i}}\right)$ Masing-Masing Saham Periode Desember 2013 - November 2016

\begin{tabular}{|l|c|c|}
\hline No. & Kode Saham & $\boldsymbol{\beta}_{\mathbf{i}}$ \\
\hline 1. & ADRO & 1,52355 \\
\hline. & AKRA & 0,337429 \\
\hline
\end{tabular}


Analisis Saham Syariah Efisien dengan Pendekatan...

\begin{tabular}{|l|c|c|}
\hline No. & Kode Saham & $\boldsymbol{\beta}_{\mathbf{i}}$ \\
\hline 3. & ASII & 1,655422 \\
\hline 4. & BSDE & 1,945347 \\
\hline 5. & ICBP & 1,021628 \\
\hline 6. & INDF & 1,192018 \\
\hline 7. & KLBF & 1,202072 \\
\hline 8. & LSIP & 0,581622 \\
\hline 9. & SMRA & 2,207159 \\
\hline 10. & TLKM & 0,859363 \\
\hline 11. & UNTR & 0,852376 \\
\hline 12. & UNVR & 0,59428 \\
\hline 13. & WIKA & 1,717541 \\
\hline
\end{tabular}

Tingkat Pengembalian yang Diisyaratkan (Required Rate of Return RRR)

Hasil analisis menunjukkan saham PT. Summercon Agung memiliki tingkat pengembalian yang diisyaratkan tertinggi sebesar 0,006238519 atau 0,6238519 \%. Sementara yang terendah adalah saham PT. AKR Corporindo sebesar 0,005737431 atau 0,5737431\%. Berikut adalah hasil perhitungan RRR.

Tabel 3. Tingkat Pengembalian yang Diisyaratkan Periode Desember 2013 - November 2016

\begin{tabular}{llllll}
\hline No. & Kode Saham & $\mathbf{R}_{\mathrm{m}}$ & SBIS & $\boldsymbol{\beta}_{\mathrm{i}}$ & $\mathbf{R R R}=\mathbf{S B I S}+\left(\mathbf{R}_{\mathrm{m}}-\mathbf{S B I S}\right) \boldsymbol{\beta}_{\mathrm{i}}$ \\
\hline 1 & ADRO & 0,005915 & 0,005647 & 1,52355 & 0,006055312 \\
2 & AKRA & 0,005915 & 0,005647 & 0,337429 & 0,005737431 \\
3 & ASII & 0,005915 & 0,005647 & 1,655422 & 0,006090653 \\
4 & BSDE & 0,005915 & 0,005647 & 1,945347 & 0,006168353 \\
\hline
\end{tabular}

Economica: Jurnal Ekonomi Islam - Volume 8, Nomor 1 (2017) 
Zainul Hasan Quthbi

\begin{tabular}{llllll}
\hline No. & Kode Saham & $\mathbf{R}_{\mathrm{m}}$ & SBIS & $\boldsymbol{\beta}_{\mathrm{i}}$ & $\mathrm{RRR}=\mathrm{SBIS}+\left(\mathbf{R}_{\mathrm{m}}-\mathrm{SBIS}\right) \boldsymbol{\beta}_{\mathrm{i}}$ \\
\hline 5 & ICBP & 0,005915 & 0,005647 & 1,021628 & 0,005920796 \\
6 & INDF & 0,005915 & 0,005647 & 1,192018 & 0,005966461 \\
7 & KLBF & 0,005915 & 0,005647 & 1,202072 & 0,005969155 \\
8 & LSIP & 0,005915 & 0,005647 & 0,581622 & 0,005802875 \\
9 & SMRA & 0,005915 & 0,005647 & 2,207159 & 0,006238519 \\
10 & TLKM & 0,005915 & 0,005647 & 0,859363 & 0,005877309 \\
11 & UNTR & 0,005915 & 0,005647 & 0,852376 & 0,005875437 \\
12 & UNVR & 0,005915 & 0,005647 & 0,59428 & 0,005806267 \\
13 & WIKA & 0,005915 & 0,005647 & 1,717541 & 0,006107301 \\
\hline
\end{tabular}

Teori CAPM mengasumsikan bahwa risiko sistematis menggambarkan return suatu saham. Hasil analisis diatas membuktikan bahwa risiko yang lebih tinggi akan memberikan return yang lebih tinggi pula karena risiko berbanding positif dengan return secara teoritis. Saham PT. Summarecon Agung dikategorikan saham paling agresif dalam penelitian ini dengan beta tertinggi, namun tingkat pengembalian yang diisyaratkan PT. Summarecon Agung juga merupakan yang tertinggi. Sementara PT. AKR Corporindo memiliki beta dan tingkat pengembalian yang diisyaratkan paling rendah diantara saham yang diadikan sampel pada penelitian ini.

\section{SML (Security Market Line)}

SML merupakan penggambaran secara grafis hubungan antara risiko sistematis $(\beta)$ dengan RRR untuk semua saham, baik yang tergolong efisien maupun tidak. Pada penelitian ini SML menggambarkan hubungan yang seimbang dari masing-masing saham individu. Artinya penelitian ini menggambarkan hubungan hight risk hight return dan sebaliknya low risk low return. Penggambaran SML dari 13 sampel pada penelitian ini adalah sebagai berikut: 
Analisis Saham Syariah Efisien dengan Pendekatan...

Gambar 1. SML (Security Market Line)

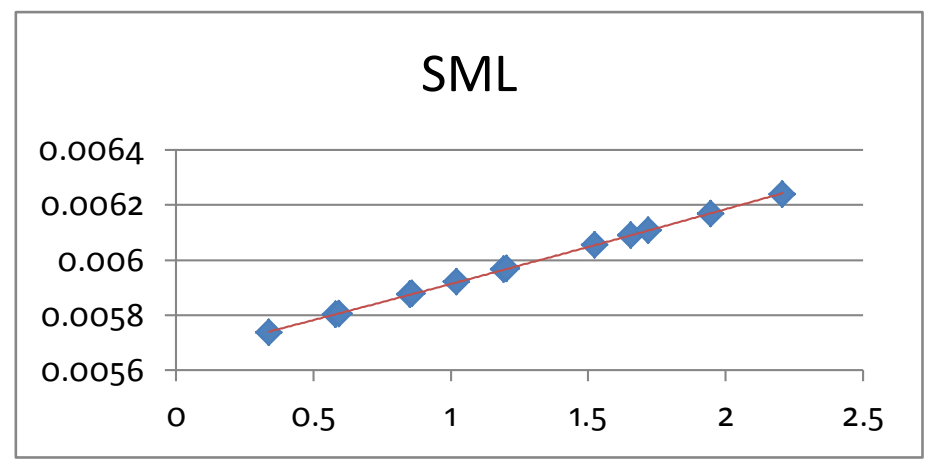

\section{Pengelompokan Saham-saham Efisien}

Pengambilan keputusan untuk menentukan saham efsien adalah dengan membandingkan pengembalian saham individu aktual dengan RRR. Apabila pengembalian saham individu aktual lebih besar dari RRR ( $\left.R_{i}>R R R\right)$ maka saham tergolong efisien. Pada penelitian ini perbandingan tersebut dapat ditunjukkan dengan gambar berikut:

Gambar 2. Penggolongan Saham Efisien

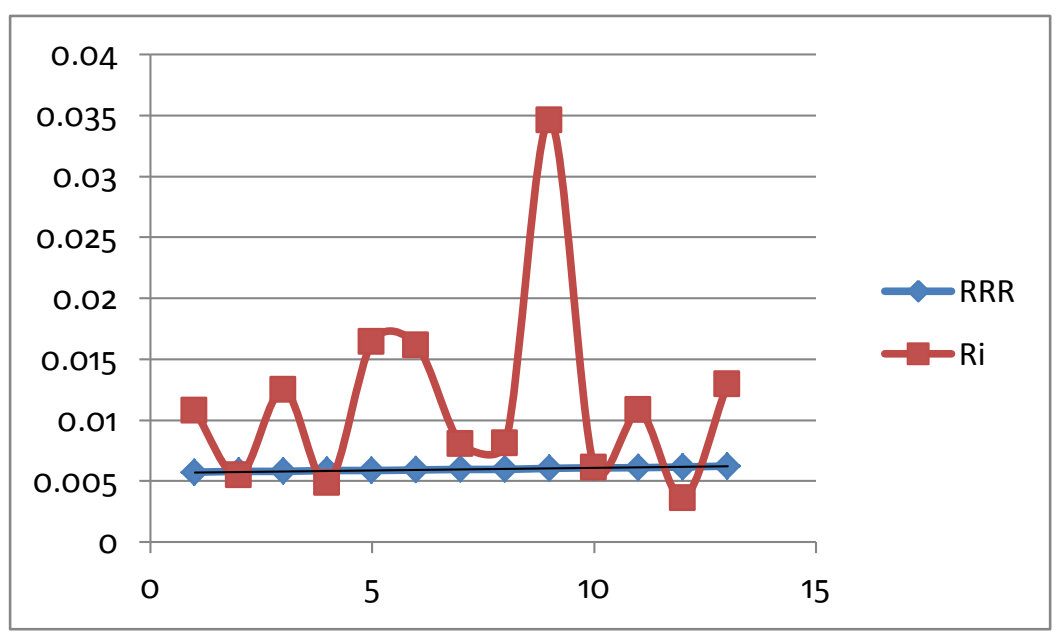

Economica: Jurnal Ekonomi Islam - Volume 8, Nomor 1 (2017) 
Zainul Hasan Quthbi

Pada gambar di atas terdapat 4 saham syariah yang tergolong tidak efisien karena posisi pengembalian saham individu aktualnya berada di bawah RRR. Adapun evaluasi secara menyeluruh dari 13 sampel pada penelitian ini adalah sebagai berikut :

Tabel 4. Evaluasi Saham yang Tergolong Efisien dan Tidak Efisien

\begin{tabular}{lllll}
\hline No. & Kode Saham & $\mathbf{R}_{\mathbf{i}}$ & RRR & Evaluasi Saham \\
\hline 1 & ADRO & 0,034601 & 0,006055312 & Efisien \\
2 & AKRA & 0,010768 & 0,005737431 & Efisien \\
3 & ASII & 0,006087 & 0,006090653 & Tidak Efisien \\
4 & BSDE & 0,00363 & 0,006168353 & Tidak Efisien \\
5 & ICBP & 0,016131 & 0,005920796 & Efisien \\
6 & INDF & 0,008047 & 0,005966461 & Efisien \\
7 & KLBF & 0,008091 & 0,005969155 & Efisien \\
8 & LSIP & 0,005462 & 0,005802875 & Tidak Efisien \\
9 & SMRA & 0,012948 & 0,006238519 & Efisien \\
10 & TLKM & 0,016432 & 0,005877309 & Efisien \\
11 & UNTR & 0,004862 & 0,005875437 & Tidak Efisien \\
12 & UNVR & 0,01249 & 0,005806267 & Efisien \\
13 & WIKA & 0,010812 & 0,006107301 & Efisien \\
\hline
\end{tabular}

Dari tabel tersebut dapat disimpulkan bahwa saham ASII, BSDE, LSIP dan UNTR tergolong saham yang tidak efisien. Keputusan yang diambil investor pada saham yang tidak efisien seharusnya overpriced (menjual saham). Sementara 9 saham lainnya tergolong efisien sehingga investor bisa mengambil keputusan underprice (membeli saham). Sesuai dengan kategori investor rasional yang akan memilih saham-saham effisien dan tidak akan memilih saham-saham yang tidak efisien.

Setelah menentukan saham-saham efisien, investor dapat menentukan saham prioritas dengan mengetahui kinerja saham tersebut. Pada penelitian 
ini dilakukan pemeringkatan berdasarkan kinerja terbaik dari saham-saham syariah menggunakan RVAR. Adapun hasilnya sebagai berikut:

Tabel 5. Perhitungan RVAR Saham Syariah

Periode Desember 2013 - November 2016

\begin{tabular}{lllll}
\hline Peringkat & $\begin{array}{l}\text { Kode } \\
\text { Saham }\end{array}$ & $\begin{array}{l}\text { Exces Return } \\
\left(\mathbf{R}_{\mathbf{i}}-\mathbf{S B I S}\right)\end{array}$ & Std. Deviasi & $\begin{array}{l}\text { RVAR } \\
\text { (Excess Return / Std. } \\
\text { Deviasi) }\end{array}$ \\
\hline 1 & ADRO & 0,028954 & 0,111944797 & 0,258645338 \\
2 & TLKM & 0,010785 & 0,058833505 & 0,183313914 \\
3 & ICBP & 0,010484 & 0,065116318 & 0,16100419 \\
4 & UNVR & 0,006843 & 0,056502058 & 0,121110632 \\
5 & AKRA & 0,005121 & 0,078826262 & 0,064965658 \\
6 & SMRA & 0,007301 & 0,119045421 & 0,061329532 \\
7 & WIKA & 0,005165 & 0,1078964 & 0,047869994 \\
8 & KLBF & 0,002444 & 0,061788646 & 0,039554193 \\
9 & INDF & 0,0024 & 0,075325512 & 0,031861715 \\
10 & ASII & 0,00044 & 0,072294433 & 0,006086222 \\
11 & LSIP & $-0,000185$ & 0,117502618 & $-0,001574433$ \\
12 & UNTR & $-0,000785$ & 0,075461418 & $-0,010402667$ \\
13 & BSDE & $-0,002017$ & 0,088190595 & $-0,02287092$ \\
\hline
\end{tabular}

Dari 13 saham syariah yang digunakan sebagai sampel telah diperoleh urutan peringkat dalam pengambilan keputusan investasi. Di mana saham PT. Adaro Energy menjadi saham yang paling dianjurkan kepada investor dari 13 sampel pada penelitian ini karena memiliki nilai RVAR paling besar. Sebagaimana diketahui bahwa semakin besar nilai RVAR suatu saham menunjukkan semakin baiknya kinerja saham tersebut. 
Zainul Hasan Quthbi

\section{Simpulan}

SCAPM (Shari'a Compliant Asset Pricing Model) merupakan bentuk modifikasi dari CAPM (Capital Asset Pricing Model) yang lahir di tengah lingkungan konvensional yang berbasis bunga. SCAPM ini bertujuan membentuk suatu model asset pricing dalam kerangka syariah. Penelitian ini menggunakan SBIS (Sertifikat Bank Indonesia Syariah) untuk menggantikan komponen $\mathrm{R}_{\mathrm{f}}$ yang berlandaskan bunga.

Dari seluruh saham syariah yang terdaftar di JII (Jakarta Islamic Index) terdapat 19 saham syariah yang konsisten terdaftar dari periode Desember 2013 hingga November 2016 dan dari 19 saham syariah tersebut 13 di antaranya memiliki rata-rata pengembalian individu positif. Berdasarkan hasil penelitian dari 13 sampel yang digunakan, semuanya menggambarkan hubungan yang linear antara risiko sistematis $(\beta)$ dengan pengembalian yang diisyaratkan (RRR). Sementara dari evaluasi efisiensi saham, terdapat 9 saham syariah yang efisien dan 4 lainnya tergolong tidak efisien. Saham PT. Adaro Energy menjadi saham paling dianjurkan kepada investor karena memiliki nilai RVAR paling besar.

\section{Daftar Pustaka}

Elbannan, Mona A. 2015. "The Capital Asset Pricing Model: An Overview of The Theory." International Journal of Economic and Finance (, The Capital Asset Pricing Model: An Overview of The Theory. InternationaCanadian Center of Science and Education) 7, no. 1, 222.

Hadi, Irham Fahmi dan Yovi Lavianti. 2011. Teori Portofolio dan Analisis. Bandung: Alfabeta.

Halim, Abdul. 2005. Analisis Investasi. Jakarta: Salemba Empat.

Hanif, Muhammad. 2011. "Risk and Return Under Shari'a Framework: An Attempt to Develop Shari'a Compliant Asset Pricing Model (SCAPM)." Pakistan Journal Commer Social Science (Pakistan Journal Commer Social Science) 5, no. 2. 
Analisis Saham Syariah Efisien dengan Pendekatan...

Hartono, Jogiyanto. 2010. Menguji Pasar Modal Akibat Suatu Peristiwa. Yogyakarta: BPFE.

-. 2013. Teori Portopolio dan Analisis Investasi. Vol. Edisi Ketujuh. Yogyakarta: BPFE.

Husnan, Suad. 2009. Teori Portopolio dan Analisis Sekuritas. Edisi Keempat. Yogyakarta: UPP STIM YKPN.

Ismail, Wan Abdillah Wan. 2015. "The Quality of Earnings in ShariahCompliant Companies: Evidence From Malaysia." , et. al. The Quality of Earnings in Shariah Journal of Islamic Accounting and Business Research 6, no. 1 .

Muhammad. 2014. Manajemen Keuangan Syari'ah. Yogyakarta: LPP STIM YKPN.

Randolf B. Cohen, et. al. n.d. 2017. SSRN: http://dx.doi.org/ 10.2139/ ssrn548402 (accessed Maret 10).

Supomo, Nur Indriantoro dan Bambang. 2014. "Metodologi Penelitian Bisnis." Yogyakarta: BPFE.

William F. Sharpe, Gordon J. Alexander dan Jeffery V. Bailey. 1995. Investment. New Jersey: Prentice Hall, Inc. 